\title{
The effectiveness of quantum teaching learning model on improving the critical thinking skills and the social science concept understanding of the elementary school students
}

\author{
M. Ihsan Ramadhani *, Yulia Ayriza \\ Universitas Negeri Yogyakarta. Jalan Colombo No. 1, Karangmalang, Yogyakarta, 55281, Indonesia \\ *Corresponding Author. Email: ihsandikdas@gmail.com
}

Received: 19 October 2016; Revised: 29 January 2019; Accepted: 5 April 2019

\begin{abstract}
The study aims at identifying the difference on the effectiveness between the Quantum Teaching Learning Model and the Expository Learning Model in improving the students' critical thinking skills and concept understanding in Social Science. The method that has been selected is the quasiexperimental research using the non-equivalent pre-test and post-test control group design. Then, the subjects in the study are 22 students of Grade IV Gunung Raja State Elementary School as the experimental group and 23 students of Grade IV Pulau Sari 1 State Elementary School as the control group from the Academic Year 2015/2016. The selection of the experimental group and the control group is based on the students' similar characteristics with random approach. Based on the results of the random sampling technique implementation, the students from Gunung Sari State Elementary High School is provided with the Quantum Teaching Learning Model (experimental group) while the students from Pulau Sari 1 State Elementary High School is provided with the expository learning model (control group). In analyzing the data that have been gathered, the researcher has conducted the independent sample t-test and the paired sample t-test with SPSS 23 for Windows. The results of the study show that the Quantum Teaching Learning Model has bee more effective in comparison to the Expository Learning Model for improving the students' critical thinking skills with significance value $0.000<0.050$. In the same time, the results of the study also show that the Quantum Teaching Learning Model has been more effective in comparison to the Expository Learning Model for improving the students' Social Science concept understanding with significance value $0.000<0.050$.
\end{abstract}

Keyword: quantum teaching learning model, critical thinking skills, social science concept understanding

How to Cite: Ramadhani, M., \& Ayriza, Y. (2019). The effectiveness of quantum teaching learning model on improving the critical thinking skills and the social science concept understanding of the elementary school students. Jurnal Prima Edukasia, 7(1), 47-57. doi:https://doi.org/10.21831/jpe.v7i1.11291

d.

https://doi.org/10.21831/jpe.v7i1.11291

\section{Introduction}

A nation of success is a nation that holds the capacity to benefit all resources that have been available including the human ones. Departing from the statement, in order to empower the Indonesian human resources, as having been mandated in the Law of National Education System Number 20 of 2003, education aims at developing the capacity and the shaping the characteristics of a dignified nation in order to brighten the life of the nation and to develop the potentials of the students so that they will be faithful, pious, noble, health, knowledgeable, capable, creative, independent, democratic and responsible citizen.

Through education, a nation strives to achieved advancement on multiple domains such as education, economy, social, politics, knowledge and technology. Through education, a nation also strives to achieve certain objectives and aspiration that have been dreamed of. Then, education involves a learning process between teachers and students; without one of them, like the students for example, the learning process will certainly be incomplete. In other words, it might be inferred that education refers to the activities that individuals, group of individuals or institutions perform in order to assist other 
Jurnal Prima Edukasia, 7 (1), 2019 - 48

M. Ihsan Ramadhani, Yulia Ayriza

individuals or group of individuals to achieve the educational objectives.

In order to achieve that end, the government has held several educational programs by opening more educational degrees from elementary school level to university level. The reason is that school is a wide teaching system that contains the components of learning process, curriculum, learning model, media, teaching system and learning evaluation in addition to teachers and students. All of these components are connected from one to another. Not to mention, there are also other components that might contribute significant impact to the learning process within the school namely learning objective, learning method, learning media and display, and also learning results evaluation.

Despite the efforts by the government, in the practice not all teachers in a school might implement the learning process in a normative and ideal manner; for example, a teacher tends to be passive in creating an enjoyable learning situation. On certain learning materials in a school the learning process might be well implemented but might not be well implemented in another school. In addition, different teachers might conduct different learning process and thus lead to different learning results. Similar situation has also been experienced by Gunung Raja State Elementary School in the County of Tanah Laut, the Province of South Borneo. In the second semester of Academic Year 2014/2015, the learning process of Social Science under the material "The Development of Production, Communication and Transportation Technology" that has been implemented under the Educational Unit Level Curriculum (KTSP, Kurikulum Tingkat Satuan Pendidikan) provides a description that there are still several obstacles that lead to the low scores on Social Science especially with regards to the critical thinking skills and the Social Science concept understanding. From the results of observation and interview, it is apparent that the learning model that has been implemented within the learning process is the Expository Learning Model which is teachercentered. As a result, generally the teacher's assessment is still product-oriented by providing the students with direct learning experience through the mastery of Social Science critical thinking skills and concept understanding.

Knowledge is not transferred but instead knowledge is built based on experiences within the learning process in which a teacher should be able to play his or her role as a good facilitator for having interaction with the students and applying his or her knowledge into events, minds, feelings and experiences within the context of the daily life. After the connection has been established between the teachers and the studens, the teachers will be able to lead the students into their world easily. Then, one of the ways for maximizing the learning process is designing and implementing active, innovative, creative, effective and enjoyable lesson plan and learning process. Such design and implementation is obligatory for uncovering and molding the students' potentials. According o Piaget (Shaffer \& Kupp, 2010, pp.253-277), in order to uncover and mold their potentials the students should go through the following four stages of development: (1) sensoric-motoric stage ( 0 -2 years old); (2) preoperational stage (2-7 years old); (3) concrete operational stage (7-11 years old); and (4) formal operational stage (11-12 years old). Furthermore, Piaget (Santrock, 2012, p.329) states that in the final stage of development the students will be able to perform concrete operation and logical reasoning as long as the reasoning might be applied into the specific or concrete example. Specific to the context of the study, the respondents in the study, namely the Grade IV students, fall into the concrete operational stage because their range of age is 7-11 years old.

Teachers should be able to innovate and to create interesting classroom situation for the students in order that conducive learning process might be created in the efforts of improving the students' critical thinking skills. According to Dewey (Fisher, 2009, p.2), critical thinking is an active process in which an individual do not only immediately accept the ideas and the information provided by other people but also thinks about the ideas and the information in deeper contemplation by means of interpretation, investigation and verification. Teachers have a very vital role in the domain of education; they hold the moral responsibility for turning the students into individuals with critical thinking skills. Furthermore, Apriani \& Wangid $(2015$, p.16) state that the good elements should be internalized into the students as early as possible in order to serve as a guideline in reasoning, communicating and behaving process throughout the life. With regards to the statement, critical thinking skills aim at improving the students' activeness in interpreting, analyzing and even manipulating information that they have retrieved previously so that the information will not be monotonous. Thereby, critical thinking skills will appear by the 
Jurnal Prima Edukasia, 7 (1), 2019 - 49

M. Ihsan Ramadhani, Yulia Ayriza

time the students have been able to associate the new information with the information that they have memorized and also to connect or re-arrange and even to develop the new information in order to achieve an objective or to solve a problem under a difficult situation. In other words, with the mastery of critical thinking skills the students are expected to not immediately retrieve certain information without filtering it (Anindyta \& Suwarjo, 2014, p.11). Then, if the critical thinking skills are developed in the elementary school degree continuously then the fundamental capacity of critical thinking skills will be gradually established and thus the students will be more sentitive and active during the learning process.

With regards to the previous elaboration, the successful learning process of Social Science in the elementary school might be observed from the level of concept understanding. Consequently, level of concept understanding becomes an important element in the teaching activities since concept understanding will facilitate students to identify, master, understand and describe the meaning of the concept that has been taught in the learning process. By doing so, the students are able to head toward the rate of benefitting what they have understood. The higher the level of concept understanding, materials mastery and problem-solving capacity is, the higher the rate of successful learning process for Social Science will be. In relation to the statement, good teachers are the ones who have been able to create enjoyable and comfortable learning situations so that students might develop numerous competencies, activities and self-potentials during the teaching-learning activities. Departing from the existing facts and problems, and in order to develop the students' potentials on the Social Science critical thinking skills and concept understanding, a learning model that might improve the students' activeness in the learnig process and in the same time create different learning situation is of utmost importance in order that the students will not be bored during the learning process.

In relation to the learning model, Quantum Teaching is one of the learning model that create enjoyable and conducive learning situations through numerous effective interactions during the learning process by gathering all of the students' learning moments under the studentcentered approach. The Quantum Teaching Learning Model centers its focus on the dynamic relationship within the classroom. In addition, the
Quantum Teaching Learning Model contains the elements of gamework and teamwork in the form of learning situations that might create enjoyable situations and encourage the students to perform their critical thinking skills. According to Thomas (2010, p.10), in order to lead the students into mutual cooperation certain procedures should be performed during the teamwork activities and the interactive process within the teamwork activities might develop the interpersonal intelligence of each students. The students who are able to establish interaction during the learning process will be able to understand, gather, analyze, synthesize and verify the information from the materials that have been delivered by their teachers. The statement goes in accordance to that of A'la (2012, p.19), who has found in his study that the Quantum Teaching Learning Model offers new ideas with regards to how to create far better and more promising environment for the students within the learning process so that the gap among the students might be minimized and even be eliminated.

Exercising the students' critical thinking skills by means of Quantum Teaching Learning Model in the elementary school degree is very necessary to perform. The reason is that the Quantum Teaching Learning Model provides meaningful learning experience through the learning moments in which the students have the opportunities to share their opinions both in the oral and written manner. The objective of this idea is that the students will be encouraged and motivated to perform their critical thinking skills in the school based on their experience and fundamental knowledge. Within the learning process of the Quantum Teaching Learning Model, teachers might create cognitive conflicts in order that the students' will be stimulated to perform their critical thinking skills and to understand the concept of Social Science through the student-centered learning process.

An innovation within the implementation of lerning model should provide flexibility for the students to be active within the learning process, especially in developing their concept understanding. Villafane (2011, p.102) explains that therefore to be successful students must be able to make connections between the new information and their existing knowledge. New understanding or information that students have retrieved are an important element in the learning process. In accordance to the importance of new understanding or information, the Quantum 
Jurnal Prima Edukasia, 7 (1), 2019 - 50

M. Ihsan Ramadhani, Yulia Ayriza

Teaching Learning Model is able to develop the students' concept understanding, including the one in the domain of Social Science, so that the students will not easily forget the relevant concepts that they have learned. In the same time, the Quantum Teaching Learning Model is able to encourage the students to be more active and independent in accordance to the statement by Kosasih \& Sumarna (2013, p.89) who have found that the Quantum Teaching is an innovative learning model that sets the orientation toward the students and is highly effective as well because the learning model is able to improve the students' learning achievement significantly. Furthermore, Jaelani (Suryani, Sari, Milfayetty \& Dirhamsyah, 2014, p.39) states that the interaction that occurs in the Quantum Teaching Learning Model is highly necessary in creating enjoyable learning moments through the adjustment toward the surrounding environment; by doing so, the students' understanding might be elicited. The role of both teachers and students in learning process is complementary. Teachers serve to translate the learning contents into the necessary information for understanding the learning materials through a series of appropriate learning activities. Then, the translation of the content should be in accordance to the cognitive concrete aspect of numerous learning strategies that might be beneficial and enjoyable for the students in order to achieve the objective of active, effective and enjoyable learning process. Eventually, the teachers will be able to understand the students' situations by mastering the materials that they should deliver to the students.

As having been discussed, the Quantum Teaching Learning Model is able to create enjoyable learning situations for the students under the principle of meaningfulness while in the same time affords to enter the students' world of joy so that the learning situations will be able to deliver meaningful messages into the world. If this idea is implemented constantly then conducive and enjoyable learning situations will be established under the students' learning objective and cutscore. Furthermore, according to Kusno (2011, p.84), the Quantum Learning Teaching Model is able to encourage the student to think realistically and creativly, to be able to execute planning and to identify and condition the learning process ideally and optimistically in order to achieve the learning success; consequently, the teachers will merely serve as a facilitator so that the students will not deviate from the learning concept that has been planned. Then, the implementation of Quantum Teaching Learning Model is known by the following term: TANDUR (Tumbuhkan or Develop, Alami or Experience, Namai or Name, Demonstrasikan or Demonstrate, Ulangi or Repeate and Rayakan or Celebrate) (Wena, 2013, pp.165-166). Then, the term TANDUR might elaborated into several stages within the implementation of Quantum Teaching Learning Model and the stages are as follows: (1) developing the students' interest to attend learning process (Tumbuhkan or Develop); (2) facilitating the learning process to attain learning experiences by means of experiment (Alami or Experience); (3) guiding the students to draw conclusions or verify based on the information and the facts that have been found (Namai or Name); (4) providing opportunities for the students to present the results of the groupwork activities that they have performed (Demonstrasikan or Demonstrate); (5) directing the students to re-internalize the knowledge that they have mastered into certain problems in order to strengthen the neural network into the concept understanding of Social Science and to perform the students' critical thinking skills (Ulangi or Repeat); and (6) holding celebrations as part of positive feedback upon the students' efforts during the learning process (Rayakan or Celebrate).

Departing from the overall elaboration, it is deemed necessary that a study on the different rate of effectiveness between the Quantum Teaching Learning Model and the Expository Learning Model for improving the students' critical thinking skills and concept understanding in Social Science should be pursued. With regards to the study, the subjects will be the students of Grade IV Gunung Raja State Elementary School, the County of Tanah Laut, the Province of South Borneo.

\section{Method}

The study relied on the use of quantitative approach, specifically the quasi-experimental research, with pre-test and non-equivalent pretest and post-test control group design. The subjects in the study were 22 students from Grade IV Gunung Raja State Elementary School as the experimental group and 23 students from Grade IV Pulau Sari 1 State Elementary School as the control group; all of these students were selected randomly in order to participate into the study. Then, the study took place in the beginning of the second semester of Academic Year 2015/2016 or 
Jurnal Prima Edukasia, 7 (1), 2019 - 51

M. Ihsan Ramadhani, Yulia Ayriza

specifically from March until April 2016. There were three variables that had been assigned within the conduct of the study namely the Quantum Teaching Learning Model as the independent variable and also the students' Social Science critical thinking skills and the students' Social Science concept understanding with Expository Learning Model as the comparison.

The data for the study were gathered by means of test administration. In order to assess the students' Social critical thinking skills and concept understanding, a multiple choice-type test item had been developed and adjusted to the cognitive degree of the students in relation to the Quantum Teaching Learning Model. The test consisted of two stages namely the pre-test stage and the post-test stage. Both stages should be performed in order to assess the improvement of the students' critical thinking skills and concept understanding in Social Science at the end of the learning process.

The validity of the instrument within the study was based on the content validity; the content validity was assessed by designing the guidelines of the instrument and sending the guidelines to the expert judgment. After the validators (the material experts) in the expert judgment stage had an agreement over the guidelines of the instrument, the instrument was sent to the experimental group and the control group for experiment during the pre-test and the post-test stage. The results of the test then served as the basis of item selection with criterion $r>$ 0.30 (Azwar, 2012, p.16). In addition, the validity of the instrument is also based on the results reliability test by referring to the coefficient of Cronbach's Alpha. Next, the study proceeded as follows: (1) the researcher conducted the presurvey activities and asked for the study permit to both state elementary schools; (2) the researcher designed and tested the instrument; (3) the researcher held a coordination meeting with the relevant teachers and presented the Quantum Teaching Learning Model and its impact on the improvement of the students' critical thinking skills and concept understanding in Social Science; (4) the researcher developed the Quantum Teaching Learning Model for the experimental group and the Expository Learning Model for the control group along with the relevant teachers; (5) the researcher performed the pre-test stage and continued to the experiment; (6) the researcher performed the post-test stage after the treatment had been completed; and (7) the researcher analyzed the data from the students' critical thinking skills and concept understanding in Social Science.

The data that had been gathered were analyzed descriptively and inferentially. The descriptive analysis was performed in order to present the data from the preliminary condition (pre-test stage) and the final condition (post-test stage) for the students' critical thinking skills and concept understanding in Social Science. In order to describe the data well, the aspects of descriptive statistics such as mean, median, variance, minimum score and maximum score were presented in tables. On the contrary, the inferential analysis was performed in order to test the hypotheses in the study; however, prior to conducting the hypothesis test the researcher should perform the analysis prerequisite test that consisted of normality test and homogeneity test.

The hypothesis test itself employed the $\mathrm{t}$ test data analysis namely the paired sample t-test and the independent sample t-test with the assistance by SPSS 23 for Windows. The paired sample t-test was performed in order to assess improvement on the students' critical thinking skills and concept understanding in Social Science or not. The assessment on the improvement was based on the influence of each learning model, namely the Quantum Teaching Learning Model and the Expository Learning Model, that might be described from the results of both the pre-test stage and the post-test stage. On the other hand, the independent sample t-test was performed in order to assess the effectiveness of the Quantum Teaching Learning Model for the experimental group and the Expository Learning Group for improving the students' critical thinking skills and concept understanding in Social Science.

\section{Results and Discussions}

\section{Descriptive Analysis}

The descriptive analysis is performed in order to present the data that has been attained from the pre-test stage and the post-test stage between the experimental group and the control group with regards to the improvement of students' critical thinking skills and concept understanding in Social Science. The elements of the descriptive analysis that have been used consist of mean, median, deviation standard, variance, minimum score and maximum score. The results of the descriptive analysis from the pre-test stage with regards to the students' critical 
Jurnal Prima Edukasia, 7 (1), 2019 - 52

M. Ihsan Ramadhani, Yulia Ayriza

thinking skills in Social Science might be consulted in Figure 1.

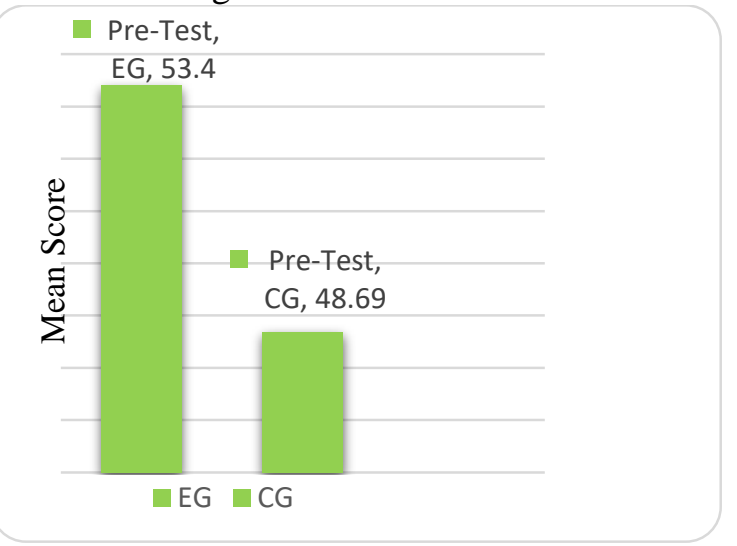

Figure 1. The Histogram for the Mean Score in the Pre-Test Stage of Students' Critical

Thinking Skills in Social Science

From the results that have been described in Figure 1, it is apparent that the pre-test score of the students' critical thinking skills between the experimental group and the control group is 53.40and 48.69 respectively. The results of the students' critical thinking skills from both groups are analyzed further by using the independent sample t-test in order to confirm that both groups do not have significantly similar gap since the experimental group has been treated by using the Quantum Teaching Learning Model while the control group has been treated by using the Expository Learning Group.

Then, the results of the descriptive analysis for the pre-test stage with regards to the students' concept understanding in Social Science might be consulted in Figure 2.

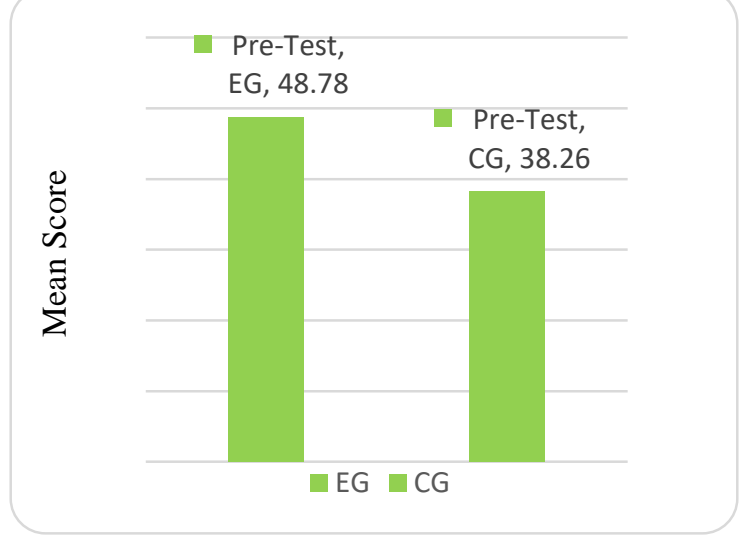

Figure 2. The Histogram for the Mean Score in the Pre-Test Stage of Students' Concept

Understanding in Social Science

From the results in Figure 2, it is apparent that the pre-test score of the students' concept understanding between the experimental group and the control group is 48.78 and 38.26 respectively. The results of the students' concept understanding from both groups are analyzed further by using the independent sample t-test in order to confirm that both groups do not have significantly similar gap since the experimental grop has been treated by using the Quantum Teaching Learning Model while the control group has been treated by using the Expository Learning Model.

Next, the results of descriptive analysis for the post-test stage with regards to the students' critical thinking skills in Social Science might be consulted in Figure 3.

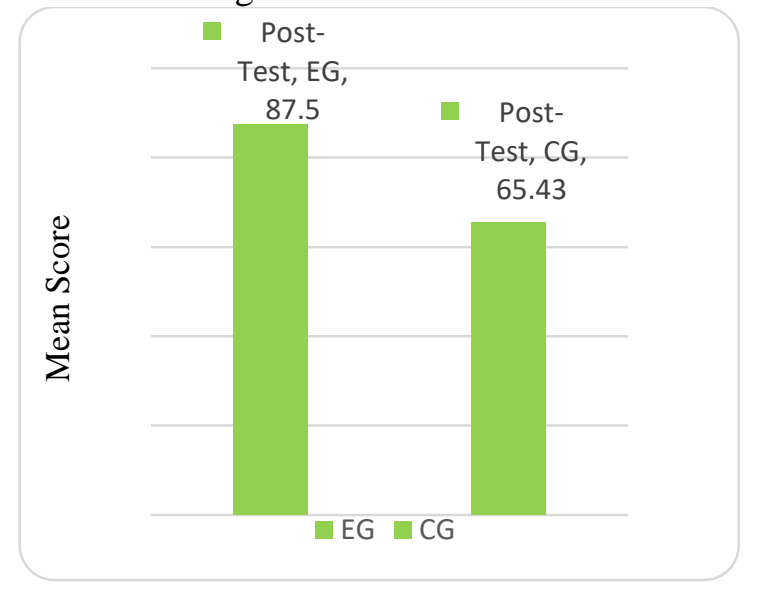

Figure 3. The Histogram for the Mean Score in the Post-Test Stageof Students' Critical

Thinking Skills in Social Science

Based on the results in Figure 3, it is apparent that post-test score of the students' critical thinking skills between the experimental group and the control group is 87.50 and 65.43 respectively. The results of the students' critical thinking skills from both groups are analyzed further by using the independent sample t-test in order to confirm that both groups do not have significantly similar gap since the experimental grop has been treated by using the Quantum Teaching Learning Model while the control group has been treated by using the Expository Learning Model.

Last but not the least, the results of descriptive analysis for the post-test stage with regards to the students' concept understanding in Social Science might be consulted in Figure 4. 
Jurnal Prima Edukasia, 7 (1), 2019 - 53

M. Ihsan Ramadhani, Yulia Ayriza

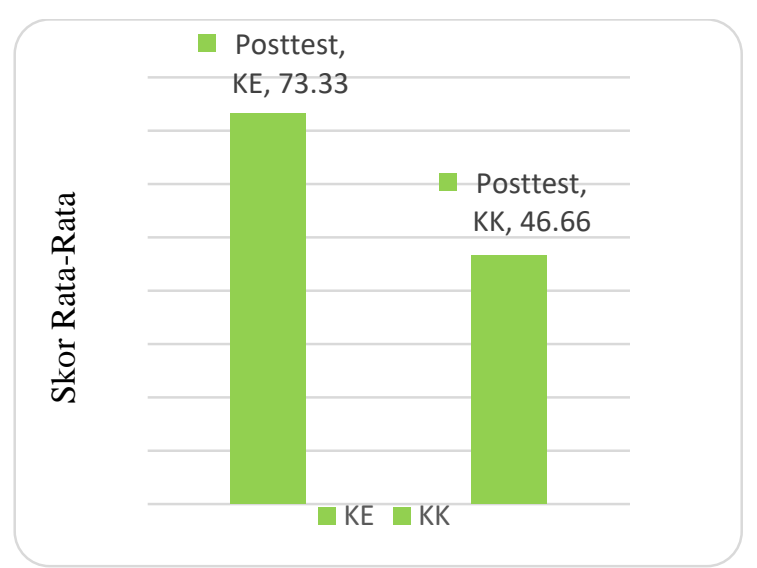

Figure 4. The Histogram for the Mean Score in the Post-Test Stageof Students' Concept

\section{Understanding in Social Science}

Based on the results in Figure 4, it is apparent that post-test score of the students' concept understanding between the experimental group and the control group is 73.33 and 46.66 respectively. The results of the students' concept understanding from both groups are analyzed further by using the independent sample t-test in order to confirm that both groups do not have significantly similar gap since the experimental grop has been treated by using the Quantum Teaching Learning Model while the control group has been treated by using the Expository Learning Model.

\section{Results of Analysis Prerequisite Test}

The normality test is conducted in the pretest stage and the post-test stage of both the experimental group and the control group in order to identify whether the samples are from the normally distributed population or not. The prerequisite is as follows: the rate of significance $(\alpha)$ is 0.05 if the decision making for the pre-test and the post-test value is higher than 0.05 . The normality test for pre-test stage and the post-test stage is performed by running the SPSS 23 for Windows program.

Based on the summary from the normality test of the pre-test stage and the post-stage, the significance value for the students' critical thinking skills in the experimental group is 0.203 (pre-test) and 0.163 (post-stage) while the significance value for the students' critical thinking skills in the control group is 0.499 (pretest) and 0.072 (post-test). Since the significance value of both groups are higher than 0.05 , it might be concluded that the data have been gathered from normally distributed population. On the contrary, based on the summary from the normality test of the pre-test stage and the poststage, the significance value for the students' concept understanding in the experimental group is 0.522 (pre-test) and 0.147 (post-stage) while the significance value for the students' concept understanding in the control group is 0.056 (pretest) and 0.156 (post-test). Once again, since the significance value of both groups are higher than 0.05 it might be concluded that the data have been gathered from normally distributed population.

Next, the homogeneity test is conducted in the pre-test stage and the post-test stage in order to identify whether the samples that have been selected are from a population that has homogenous variable or not. The homogeneity test is performed by running the SPSS 23 for Windows under the following prerequisite: the rate of significance $(\alpha)$ is 0.05 if the decision making for the pre-test and the post-test value is higher than 0.05 . The results of the homogeneity test show that the the significance value for the students' critical thinking skills in the pre-test stage and the post-test stage is higher than 0.05 namely 0.125 (pre-test stage) and 0.682 (post-test stage). In the same time, the results of the homogeneity test show that the significance value for the students' concept understanding in the pre-test stage and the post-test stage is higher than 0.05 namely 0.942 (pre-test stage) and 0.495 (post-test stage). As a result, it might be concluded that the data for the students' critical thinking skills and concept understanding are homogneous.

\section{Results of Hypothesis Test}

After the requirements of the normality test and the homogeneity test have been met, the results of the test are analyzed further by means of hypothesis test. The hypothesis test consists of two stages namely the independent sample t-test and the paired sample t-test. The results of the test might be consulted in the following section.

\section{Results of Independent Sample t-test}

Table 1. Summary from the Results of Independent Sample t-test in the Pre-Test Stage and the Post-Test Stage for the Students' Critical Thinking Skills

\begin{tabular}{|c|c|c|c|}
\hline c Data & $\mathrm{t}$-count & Sig. & ation \\
\hline $\begin{array}{l}\text { Pre-Test for Ex. } \\
\text { and Control }\end{array}$ & & 0.17 & $\begin{array}{l}\mathrm{p}>0 . \mathrm{G} \\
\text { Acce }\end{array}$ \\
\hline $\begin{array}{l}\text { Post-Test for Ex } \\
\text { and Control }\end{array}$ & 10.384 & 0.000 & $\begin{array}{l}\mathrm{p}<0.05 \text {, Ho } \\
\text { Rejected }\end{array}$ \\
\hline
\end{tabular}


Jurnal Prima Edukasia, 7 (1), 2019 - 54

M. Ihsan Ramadhani, Yulia Ayriza

Based on the summary from the independent sample t-test in Table 1, the significance value in the pre-test score for both the experimental group and the control group is higher than 0.05 namely 0.174 ; as a result, Ho is accepted. Thus, it might be concluded that there is not any significant difference on the effectiveness of the students' critical thinking skills between the experimental group and the control group. Thereby, from the perspective of the students' critical thinking skills both the experimental group and the control group are equal for comparison with the assignment of two different treatments. On the contrary, based on the summary from the independent sample t-test in Table 1 the significance value in the post-test stage for both the experimental group and the control group is lower than 0.000; as a result, Ho is rejected. As a result, it might be concluded that there is significant difference on the effectiveness of the students' critical thinking skills between the experimental group and the control group with the implementation of Quantum Teaching Learning Model for the experimental group and the Expository Learning Model for the control group. The independent sample t-test results show that the use of Quantum Teaching Learning Model is more effective in improving the students' critical thinking skills in comparison to the use of Expository Learning Model with the post-test mean score 87.50 for the experimental group and the post-test mean score 65.43 for the control group.

Table 2. Summary from the Results of Independent Sample t-test in the Pre-Test Stage and the Post-Test Stage for the Students' Concept Understanding

\begin{tabular}{|c|c|c|c|}
\hline Type of Data & $t$-count & Sig. & Information \\
\hline $\begin{array}{l}\text { Pre-Test for Ex. } \\
\text { and Control }\end{array}$ & 1.409 & 0.166 & $\begin{array}{l}\mathrm{p}>0.05, \text { Ho } \\
\text { Accepted }\end{array}$ \\
\hline $\begin{array}{l}\text { Post-Test for Ex } \\
\text { and Control }\end{array}$ & 6.998 & 0.000 & $\begin{array}{l}\mathrm{p}<0.05, \text { Ho } \\
\text { Rejected }\end{array}$ \\
\hline
\end{tabular}

Based on the summary from the results of the independent sample t-test in Table 2, the significance value in the pre-test score for both the experimental group and the control group is higher than 0.05 namely 0.166 ; as a result, Ho is accepted. Thus, it might be concluded that there is not any significant difference on the effectiveness of the students' concept understanding between the experimental group and the control group. In other words, from the perspective of the students' concept understanding both the experimental group and the control group are equal for comparison. On the contrary, based on the summary from the independent sample t-test in Table 2 the significance value in the post-test stage for both the experimental group and the control group is lower than 0.05 namely 0.000 ; as a result, Ho is rejected. Thus, it might be concluded that there is significant difference on the students' concept understanding between the experimental group and the control group with the implementation of Quantum Teaching Learning Model for the experimental group and the implementation of Expository Learning Model for the control group. The independent sample t-test results show that the use of Quantum Teaching Learning Model is more effective in improving the students' concept understanding in comparison to the use of Expository Learning Model with the post-test mean score 73.33 for the experimental group and the post-test mean score 46.66 for the control group.

\section{Results of Paired Sample t-test}

Table 3. Summary from the Results of Paired Sample t-test in the Pre-Test Stage and the PostTest Stage for the Students' Critical Thinking Skills

\begin{tabular}{lcccc}
\hline \multicolumn{1}{c}{ CTS } & $\begin{array}{c}\text { Pre- } \\
\text { Test }\end{array}$ & $\begin{array}{c}\text { Post- } \\
\text { Test }\end{array}$ & t-count & Sig. \\
\hline Experimental & 53.41 & 87.50 & -10.767 & 0.000 \\
Group & 48.70 & 65.43 & -6.897 & 0.000 \\
Control Group & 4
\end{tabular}

From the summary in Table 3, the significance value of the paired sample t-test in the pre-test stage and the post-test stage for both the experimental group and the control group is lower than 0.05 namely 0.000 ; consequently, Ho is rejected and $\mathrm{Ha}$ is accepted. Thus, it might be concluded that there is significant difference on the effectiveness of the students' critical skills before and after the treatment namely the implementation of Quantum Teaching Learning Model for the experimental group and the implementation of Expository Learning Model for the control group. The improvement in the experimental group is 34.09 with the mean score 53.41 in the pre-test stage and the mean score 87.50 in the post-test stage while the improvement in the control group is 16.73 with the mean score 48.70 in the pre-test stage and the mean score 65.43 in the post-test stage. In other words, despite the fact that both learning models are able to improve the students' critical thinking skills the Quantum Teaching Learning Model is more 
Jurnal Prima Edukasia, 7 (1), 2019 - 55

M. Ihsan Ramadhani, Yulia Ayriza

effective than the Expository Learning Model in improving the students' critical thinking skills.

Table 4. Summary from the Results of Paired Sample t-test in the Pre-Test Stage and the PostTest Stage for the Students' Concept Understanding

\begin{tabular}{lcccc}
\hline \multicolumn{1}{c}{ CU } & $\begin{array}{c}\text { Pre- } \\
\text { Test }\end{array}$ & $\begin{array}{c}\text { Post- } \\
\text { Test }\end{array}$ & t-count & Sig. \\
\hline $\begin{array}{l}\text { Experimental } \\
\text { Group }\end{array}$ & 48.78 & 73.33 & -5.122 & 0.000 \\
Control Group & 38.26 & 46.66 & -1.370 & 0.184 \\
\hline
\end{tabular}

From the summary in Table 4, the significance value of the pre-test stage and the post-test stage in the experimental group is lower than 0.05 namely 0.000 ; consequently, $\mathrm{Ho}$ is rejected and $\mathrm{Ha}$ is accepted. Thus, it might be concluded that there is significant difference on the students' concept understanding between the pre-test stage and the post-test stage with the implementation of Quantum Teaching Learning Model. On the contrary, from the summary in Table 4 the significance value of the pre-test stage and the post-test stage in the control group is higher than 0.05 namely 0.184 ; consequently, $\mathrm{Ha}$ is accepted and Ha is rejected. Thus, it might be concluded that there is not any significant difference on the students' concept understanding between the pre-test stage and the post-test stage with the implementation of Expository Learning Stage. Specifically, the improvement in the experimental group is 24.52 point with the mean score 48.78 in the pre-test stage and the mean score 24.52 in the post-test stage while the improvement in the control group is 8.40 point with the mean score 38.26 in the pre-test stage and the mean score 46.66 in the post-test stage. In overall, it might be concluded that both learning models are effective to improve the students' concept understanding but the Quantum Teaching Learning Model has higher rate of effectiveness in comparison to the Expository Learning Model.

\section{Discussions}

The study is a quasi-experimental research tat employs two groups as the sample and two learning models as the treatment namely the Quantum Teaching Learning Model and the Expository Learning Model. Both models are implemented in two different classrooms namely Grade IVA in Gunung Raja State Elementary School (for the implementation of Quantum Teaching Learning Model) and Grade IVA Pulau Sari I State Elementary School (for the implementation of Expository Learning Model). In testing the instrument, the researcher has conducted the running test in order to gather the equal preliminary data or the normally distributed and homogenous students' capacity. After the students" critical thinking skills and concept understanding have been analyzed, it is found the students from both classrooms have equal and homogenous capacity. The equal and homogenous capacity has been confirmed by the results of normality test and homogeneity test with the significance value 0.05 .

Based on the results of the paired sample ttest for the students' critical thinking skills in the pre-test stage and the post-test stage, the significance value of the experimental group is $10.767(t=-10.767)$ with the rate of significance $0.000(0.000<0.05)$. As a result, it might be concluded that there is significant difference on the effectiveness of the students' critical thinking skills in the experimental group between the pretest stage and thepost-test stage with the Quantum Teaching Learning Model as the treatment. The difference is seen from the 34.09 point of improvement between the pre-test mean score (53.41) and the post-test mean score (87.50). On the other hand, based on the results of the paired sample t-test for the students' critical thinking skills in the pre-test stage and the post-test stage the significance value of the control group is $6.897(\mathrm{t}=-6.897)$ with the rate of significance $0.000(0.000<0.05)$. Therefore, it might be concluded that there is significant difference on the effectiveness of the students' critical thinking skills in the control group between the pre-test stage and the post-test stage with the Expository Learning Model as the treatment. The difference is seen from the 16.73 point of improvement between the pre-test mean score (48.70) and the post-test mean score (65.43).

Although the control group enjoys the improvement on the effectiveness of the students' critical thinking skills before and after the learning process, the improvement is not higher than that of the experimental group. In other words, the implementation of Expository Learning Model in the learning process of Social Science has not been effective in comparison to the implementation of Quantum Teaching Learning Model. This finding is in line with the results of a study by Susiani (2013, p.3), which has found that the Quantum Teaching Learning Model puts emphasis on the significance of creating dynamic social relationship between the students and the teachers. Thereby, it might be 
Jurnal Prima Edukasia, 7 (1), 2019 - 56

M. Ihsan Ramadhani, Yulia Ayriza

concluded that the Quantum Teacing Learning Model is more effective than the Expository Learning Model in improving the students' critical thinking skills within the domain of Social Science.

In addition, the results of the paired sample t-test for the students' concept understanding show that significance value of the experimental group is $-5.122(t=-5.122)$ with the rate of significance $0.000<0.05$. Consequently, it might be concluded that there is difference on the effectiveness of the students' concept understanding between the pre-test stage and the posttest stage with the Quantum Teaching Learning Model as the treatment. The difference is seen on the 24.52 point of improvement between the pretest stage (48.78) and the post-test stage (73.30). This finding is similar to the results of a study by Elmubarok (2009, p.22), which has found that Quantum Teaching Learning Model strives to change a monotonous learning situation into an enjoyable and fun learning situation by combining the students' physical, mental and emotional potentials into an integral unity. The Quantum Teaching Learning Model puts emphasis on the cooperation between the students and the teachers in order to create a meaningful learning env ironment through optimum classroom interaction. In line with the statement, Surrachman (Rachmawati, 2012, p.479) states that the learning activites in the learning concept of Quantum Teaching Learning Model summarize events, ideas or feelings into a learning process in the form of discussion, demonstration, groupwork and assignment in accordance to the context of the elementary school students' daily life.

On the contrary, the results of the paired sample t-test for the students' concept understanding show that the significance value of the control group is $-1.370(\mathrm{t}=-1.370)$ with the rate of significance $0.184(0.184>0.05)$. As a result, it might be concluded that there is not any significant difference before and after the learning process with the Expository Learning Model as the treatment. The absence of the difference is seen from the low improvement point, namely 8.40 , between the pre-test mean score (38.26) and the post-test mean score (46.66). The use of the Expository Learning Model for the concept understanding in the domain of Social Science seems to be less interesting for the students because this model is rather student-centred. This finding is in accordance to the results of a study by Hidayah \& Pujiastuti (2016, p.187), which concludes that teacher-centred approach has been frequently implemented by the teachers in the form of lectures within the learning process and consequently the students' capacity in socialization, critical thinking skills and scientific thinking skills become less developed. In other words, it might be concluded that the Expository Learning Model is not effective for improving the students' concept understanding within the domain of Social Science. Eventually, it might be concluded further that the Quantum Teaching Learning Model is more effective for improving the students' critical thinking skills and concept understanding in the domain of Social Science. The effectiveness might be traced back on the comparison between the performance of Quantum Teaching Learning Model in the Grade IV students of Gunung Raja State Elementary School, the County of Tanah Laut, the Province of South Borneo and the performance of Expository Learning Model in the Grade IV Students of Pulau Sari I State Elementary School, the County of Tanah Laut, the Province of South Borneo.

\section{Conclusions}

Based on the results of the study and the discussions, there are two main conclusions that might be drawn. First, the Quantum Teaching Learning Model is able to more effective for improving the students' critical thinking skills in the domain of Social Science. Second, the Quantum Teaching Learning Model is more effective for improving the students' concept understanding in the domain of Social Science.

\section{References}

A'la, M. (2012). Quantum teaching. Jogjakarta: DIVA Press.

Anindyta, P., \& Suwarjo, S. (2014). Pengaruh problem based learning terhadap keterampilan berpikir kritis dan regulasi diri siswa kelas V. Jurnal Prima Edukasia, 2(2), 209-222. doi:https://doi.org/10.21831/jpe.v2i2.2720

Apriani, A., \& Wangid, M. (2015). Pengaruh ssp tematik-integratif terhadap karakter disiplin dan tanggung jawab siswa kelas III SD. Jurnal Prima Edukasia, 3(1), 12-25. doi:https://doi.org/10.21831/jpe.v3i1.4061

Azwar, S. (2012). Reliabilitas dan validitas, Pustaka Pelajar, Yogyakarta. 
Jurnal Prima Edukasia, 7 (1), 2019 - 57

M. Ihsan Ramadhani, Yulia Ayriza

DePorter, B., Reandon, M., \& Nourie, S.S., (2002).Quantum teaching: Orchestarting student success. Boston: Allyn and Bacon.

Elmubarok, Z. (2009). Membumikan pendidikan nilai. Bandung: Alfabeta.

Fisher, A. (2009). Critical thinking an intruduction. Cambridge: Cambridge University Press.

Hidayah, R., \& Pujiastuti, P. (2016). Pengaruh pbl terhadap keterampilan proses sains dan hasil belajar kognitif IPA pada siswa SD. Jurnal Prima Edukasia, 4(2), 186-197. doi:https://doi.org/10.21831/jpe.v4i2.7789

Kosasih, N., \& Sumarna, D. (2013). Pembelajaran quantum dan optimalisasi kecerdasan. Bandung: Alfabeta.

Kusno, J.P. (2011). Effectiveness of quantum learning for teaching linear program at the Muhammadiyah Senior High School of Purwokerto in Central Java, Indonesia. International Journal for Educational Studies, 4(1), 83-92.

Made, W. (2013). Strategi pembelajaran inovatif kontemporer: Suatu Tinjauan Konseptual Operasional. Jakarta: Bumi Aksara.

Presiden Republik Indonesia. (2003) Undang Undang RI Nomor 20, Tahun 2003, tentang sistem pendidikan nasional

Rachmawati, R. (2012). The implementaton quantum teaching method of graduate through up-grade hard skill and soft skill. Procedia - Social and behavioral sciences. 57, 477-485.
Santrock, J.W (2012) Life span development. New York: McGraw-Hill

Shaffer, D. R., \& Kipp, K. (2010) Developmental psychology childhood and adolescence. Belmont: Wadsworth Cengage Learning

Suryani, I., Sari, S. A., Milfayetty, S., \& Dirhamsyah, M. (2014). Increasing knowledge of the earthquake preparedness through quantum teaching model on state primary school 19 Banda Aceh. The International Journal of Social Science. 19(1), 39-44.

Susiani, K., Dantes, N., \& Tika, I. N. (2013). Pengaruh model pembelajaran quantum terhadap kecerdasan sosio-emosional dan prestasi belajar IPA siswa kelas V SD di Banyuning. Jurnal Pendidikan Dasar. Vol.3, No.1, 1-10. Retrived from http://oldpasca.undiksha.ac.id/ejournal/index.php/jurnal_pendas/article/vi ew/525

Thomas R. H. (2010). Celebrating every learner activities and strategies for creating a multiple intelligences classroom. San Fransisco: Jossey-Bass.

Villafane. (2011). Development and analysis of an instrument to assess student understanding of foundational concepts before Biochemistry Coursework. Biohemistry and Molecular Biology Education, 39, 102. 